\title{
The Existence of the Church as an Institutional Symbol of Minority Community in Dealing with Diversity in Grace Bible Church of Kedungwungu, Blitar, East Java
}

\author{
Agus Marulitua Marpaung1, LekrisAnugrahHizkia Laurika ${ }^{2}$ \\ Institut Agama Kristen Negeri Manado and Hoseo University ${ }^{1}$ InstitutInjili Indonesia Malang \\ agus.marpaung@iakn-manado.ac.id ${ }^{1}$, kris.laurika@yahoo.com²
}

\begin{abstract}
Diversity often become the reason of disruptive in community and church. Cultural and religion issues are the sensitive area to disrupt the situation. Social media easily spreads all the issues and accepted by all people without any filters.Church as part in community needs to develop a lot of approaches in dealing with diversity.Grace Bible Church in Kedungwungu, Blitar, East Java.This church is the only church in the village in which people are mostly Muslim Religion The purpose of this research is to explore how Grace Bible Church In Kedungwunguas a minor community but can exist in dealing diversities among the Moslem people as the major community. By using qualitative method with triangulation approach, researcher found that the Church should fullfill its calling in different cultures and religions society without losing its characteristics, thus exclusively church has its own belief and religious practices but inclusively the church has its way to build relationship with community.
\end{abstract}

Keywords: Diversity, Church Existence, Community.

\section{Introduction}

Diversity is a Potential resource owned by Indonesia. The diversity in Indonesiainvolves culture, race, religion, and language become an attraction for other nations to witness the diversity which is existing in Indonesia. Eka Dharma Putra said, "Indonesian society is a compound of various types of polarization, which can never be crystallized into a complete cultural identity" [1]. On the other hand diversity in Indonesia can be an issue of division in society. Diversity becomes a very sensitive issue when there is little disagreement can be a big problem.

Grace Bible Church In Kedungwungu, Blitar, East Java is a church that exist in a Muslim society. This church is the only church in Kedungwungu village. There were some churches that tried to exist but gradually they withdraw from the village, This church certainly has undergone various situations so that it can exist as a minority group. The Relevant research of this research is The research of Krido Siswanto which entitled "The Meet of Gospel and Tradition in Eastern Javanesein Contextual Mission Ministry" [2], This research focus on how the gospel can be accepted in the East Javanese tradition which includes strategies and approaches for East Javanese culture, while in this study focus on the existence the church as a minority so that it can survive in the Javanese and Muslim community. Another research is the research ofYokhebetTampubolonwhich entitled "Living in Diversity Society through Christian Education in HKBP Manado." [3]. This research focuses on learning processof the congregation 
in dealing with cultural diversity, where most members are Batak ethnic backgrounds can deal with Minahasa community which is also a majority Christian. While in this study examines the existence of the church as a minority group with different religion.

Those are the background of this research, The purpose of this research is to describe the existency of the church in minority area in its responsibility and approach in dealing the religion and cultural diversity.

\section{Method}

This research uses Qualitative research methodology, The purpose of qualitative research is to search the relation and explore the reasons of changes in social facts which can be measured [4]. First, Explore and discuss about the theoretical view about the existence of the church base on some scholars and also some biblical teaching, Second by using triangulation approach the researcher had made observation, interview and Document study.Researcherhas been stayed in Kedungwungu for 2 (two) years and directly under go how is the church is going as minority in Muslim community, interviewed elder and member of the church, Neigborhood and government officers in Kedungwungu.Third, relate all discussion with the situation of Grace Bible Church dealed with the community.

\section{Result and Discussion about Theoritical Study about The Existence of The Church}

\subsection{The Existence of The Church}

Church is believers, The gathering of people, who show the existency, solidarity, and their difference with another gathering only with one thing, God's calling [5]. The Bible's World is marked by a diversity of cultures and religions. Haran, where Abraham's parents stayed and lived, had their own "religions". Likewise with the land of Canaan, where the Family of Abraham and Sarah migrated [6]. Thus the Church has divine characteristics which the world does not have, but the church must establish a relationship with the world because it is part of God's plan to place the church into this world. Thus church existence should perform both in its calling and its society.

\subsection{Church: Its Calling And Its Society}

Church that is Holy, universal and apostolic. His calling is to worship and to witnessabout its Head, Jesus Christ, Preaching the Gospel among all nations and demonstrate its commitment through compassion ministry to various human needs and upholding truth and justice. The church is called and sent into the world by The Trinity God to declare and demonstrate the Gospel of Jesus Christ through the power of the Holy Spirit [7] Exclusively the calling of church is to worship Jesus Christ as God and Savior. The idea of Body of Christ principle shows howhow close the relation of the believers [8] In order to understand more about the Principle body of Christ,that" Church as the Body of Christ has 3 (three) kinds of relationsuchasOneness in Christ, Togetherness in Christand and dependent one and another in God's Family [9]. Therefore the Principle Relation of Body of Christ is not talking abot that in everything we are 
the same, buat in diversity we are oneness, togertherness and dependent. It is wonderful relation that the Bible Teaches

Having a divine calling does not mean that the church withdraws from the world. The Metafora of Jesus' teaching in the book of Gospel about salt of the earth and light of the world told us about The presence of the church in society should have an effort to give impact to the society.Therefore the Churchin its calling and its society should be implemented.

\subsection{The Existency of Church in Diversity:Religion and Cultural}

Diversity has the positive effects in society, First, Dependent relationship between one another, Second, lifestyle of mutual respect for one another, and Third, having a an inclusive mindset [10]. Those effects will be happened when The church is able to establish relationship with diversity. There are several different responses dealing with religions diversity : First, the Christian group who separate themselves and only focus on their own dogma, Secondly, There are also those who go to another world to do Reconquista, to convince other people both in sincerity and threaten ways to "recruit" them into their groups, the Third dialogue and believes that good response to pluralism will enrich Christianity itself [11]. Dealing with religion Diversity, Alan Race introduced an approach which so called "Tripolar Typology" which are Exclusivism, Inclusivism and Pluralism. He formulated this approach based on the history of The teaching of Salvation with all the scholars such as Ciprianus (210-228) and Karl Barth (1886-1968) as Exclusivism experts, Karl Reihner as Inclusivism experts, John Hick and Paul Knitter as Pluralism Experts. The Tripolar Typology Approach was the first step to explore The Theology of Religionin developing the ministry of the church. This approach was written based on the largest issue in church history, which was about Salvation in Christ as truth. Where the three approaches "Exclusivism, Inclusivism and Pluralism "were working undirectional and even conflict each other. In American Context Theological exclusivism is very strongly associated with more negative views of religious diversity and decreased willingness to include non-Christians in community religious life. Some scholars have argued that exclusivists' responses to religious diversity are less problematic than they appear.Such boundary construction helps to maintain a strong sense of collective identity, one way by which more strict religious groups maintain high levelsof commitment. Nonetheless, the results of this study suggest that theologically exclusive belief sheld by a substantial percentage of Americans are a significant hurdle to the full inclusion of non-Christians in American society [12].

The tripolar typology approach can be developed in a broader scope, where the relationships of the three approaches are applied not about teaching of salvation but in the area about humanity, nationality and social affairs. Exclusively every religion hastheir own belief such as in Christian :Trinity of God, Salvation through Christ And Christology. In Islam they believe that Prophet Muhammad SAW As The Last Prophetand obey Lima Rukun Islam. But inclusively every religion has spirit of Nationality, Humanity and social. Saidurrahman and Arifinsyah said that Islam let the members tolerate with other religion in muamalah area such Humanity relation, andsocial society. But in a kidahandworship, Islam strickly for bit their people to tolerate.(Saidurahman \& Arifinsyah).Through these examples both Ekslusivism Inklusivism may work orderly without conflict each other. Thus the existence of religion in diversity produces a wonderful relationship where each religion has their own characteristics and may work together in the area of humanity, nationality and social. Another approach is Inklusivism-Pluralism, This relation show The openness of the church for diversity by dialogue with another religion in term of tolerance. 
The existence of the church in cultural diversity needs to have the right approach so that it can survive to fulfil its calling. Jesus Christ was sent into the world is one of God's efforts to be presencein human culture, so that God can personally interact and convey His purpose to His people.The Process of contextualization where Gospel and Theologyare developed and implemented in the culture context [13]. Study in Theology of Contextual must consider in Theology-Misiology view. Both should be compliment each other. Tanudjaya in his writing about literature of Contextualization concluded that contextual Theology should balance between Misiology and theological view, it can produce the biblical view of Contextual theology.(Rahmiati Tahudjaya,2000)Failure in contextualization effect syncretism where almost there is no different between theology and culture. Richard Niehburexplained 5 (five) relation betweenChrist and Culture, such as : Christ Against Culture, Christ of Culture, Christ on The Culture, Christ and The Culture in Paradox, Christ transform the culture [14]. Understanding these position helps the church implementscontextual ministry. Church should be abe to devideall aspects odculture which is received, rejected, managed and transformed. Thus Church still exist in it characteristic and may exist in the culture without compromising.

\subsection{Implementation in GAAKedungwungu}

GAA Kedungwungu has started in Kedungwungu Village since 1989. It is located in a Muslim society while Christian religion is a minority community. Clifford Geertz classifies Javanese society into three varians, such as: abangan, santri, and priyayi. Eachvarian has its own cultural historical backgrounds: Abangan emphasizes animistic aspects, Santri emphasizes Islam Aspects and Priyayi emphasizes Hindu Aspect. Geertz concluded that Muslim communities in Java have different characteristics with Muslim communities outside Java, Geertz gave the term "Javanese Religion." [15]. Another Scholar Andrew M. Beatty and Woodward' research about Islam in Java. there are four types of practicing thetradition based on those two modes. Firstly, a group of reformist Santri observes normative piety exclusively. Secondly, some other Santri practice a combination of normative piety and mysticism. Thirdly, nobilityadapts mystical concepts of radical Sufis who discard normative piety.Finally, nonSantrivillagers adopt the religiosity of noble family [16]. Keadaan masyarakat Islam yang menurut penelitian Geertz dan juga Betty dan Woodward mewarnai keberagaman masyarakat muslim ada di Desa Kedungwungu,

\subsection{History Highlight of GAA Kedungwungu}

GAA Kedungwungu begun with Sukirman-Nurpiah Family on March 8, 1989. They held worship by inviting several Christian families house led by PastorDriYoso from another village. Christian worship activities in Kedungwungu village spread in village.Sukirman family were questioned by Village officer regarding worship activity. PastorDriYoso was unable to continue his ministry and was given to Mr. Welly Kandow (Evangelist from the Grace Bible Church). There were problemsoccured until some congregations felt pressure and some eventually give up. ThenSutoyo family gave their land and buildings to be used as a church building.Graduallypeople of village began to accept the existence of the church. On July 6, 1997 the inauguration of the church building. The church began to grow and There has been 7 (seven) pastors assigned such as :Pdt. DriYoso, Ev. WellyKandow, Pdt. MariksonKakombohi, Pdt. RevolTumengkol, Pdt. GedaliaMakikama, Pdt. YanceWoworuntu and Ev. Kris Laurika. 


\subsection{The Existency of GAA Kedungwunguin Javanese-Islam Society}

The presence of the Church as a minority group become the object of attention of all people. Exclusively GAA Kedungwungu teaches that the Bible is the Word of God which is the basis of the teachings and practices of the life of believers, Salvation is by Faith in Jesus Christ, and Trinity: God the Father, God the Son and the Holy Spirit. These teachings are continuously taught and preached.Those are the characteristics of the church, but in the other hand GAA Kedungwungu do not separate themselves and only focus on their own dogma and commit in Reconquista, they open dialogue to pluralism that can help their existency.Inclusively the church teaches each member to apply their belief in society. The calling of the church to the world is to demonstrate its commitment through compassion ministry to various human needs and upholding truth and justice. In humanity, nationality and social affairs area, GAA Kedungwungu has the same mission with the society and so do Islam religion as the Major society in Kedungwungu. In Islam this is muamalah area. In some occasions GAA Kedungwungu involve in some activities such as Distributing food (Sembako), ceberating Independence day (Tirakatan), Preparation of Wedding party (Rewang), Funeral, Attending invitation (Mbecek), Cleaning Village,etc . Having warm Friendship with other religion by attending each other religious activities such as during Christmas Thanksgiving, other religious people are also invited and during IdulFitri, Christians People will Sowan (Visiting / Greeting). Both Ekslusivism-Inklusivism may work orderly without conflict each other.

Culturally, the member of GAA Kedungwungu mostly Javanese people, They have known the characteristic life of java as what Geerzt's conclusion about Javanese religion. GAA Kedungwungu shows Javanese characteristics in terms of worship where there are some songs in Javanese and worship leaders often use Javanese Language. This is the Process of contextualization where Gospel and Theology are developed and implemented in the culture context. For this reason, GAA is accepted because language is a communication tool that can be easily understood.This is a challenge for every Priest who is assigned in Kedungwungu where those from other tribes need to learn Javanese Language. Some priests who were very fluently in Javanese language ere Pastor Gedalya of the Sangihe tribe and Pastor Marikson of the Sangihe tribe and married with Javanese woman. In This process of contextualization, GAA Kedungwungu still hold their belief, It becomes a filter for them to tolerate and also to reject culture custom that they will do. GAA Kedungwungu is not in position against the culture and also not in position in the culture. But They are in position Transform the culture, where GAA Kedungwungu do their effort to perform Christian lifestyle.Discipline lifestyle is one of characteristic that church member had. They must applied discipline in worship and social activities. Through it Mr. Sukirman who came from minority group was trusted to be the village head of Kedungwungu for 8 (eight) years. This is an unique thing for minority group.

Exclusively, GAA Kedungwungu in culture custom reject those ceremony which perform animistic belief. Inabangan Javanese culture still contains elements of animism such as the Offering Serajen on 01 Suro Javanese calendar. For this matter the GAA strickly rejects because it is against their belief. Through dialogue with the society and also the explanation of thePastorabout biblical view about Serajen, Member of the church commit not to do it and they may give answer to every family and societywhom questions it to them. 


\section{Conclusion}

The Existence of the Bible Church TheKedungwungugives an important lesson about the existence of the church as a minority. Although there are still a lot of things that need to be accomplished, Through this research is found that Church is able to fullfill its calling in different cultures and religions society while still showing characteristic. Through the approach GAA Kedungwungu, Tripolar Typology Approach that has been modified: Exclusivism-Inclusiveism Approach, GAAKedungwunguhave church activities according to theirbelief.And also may be opened in society in terms of social, humanity, and nationalism.

GAA Kedungwungu also uses contextual approach with the Javanese society, GAA does not escape from Javanese culture which is able to be bridge for us. Through the culture we may feel like one family but GAA also rejected cultures that is not in accordance with Christian beliefs and It can be accepted by the society through dialogue.

In this existency, GAA Kedungwungu still doing a process to be more develop, Human resources is very important to support the achievement of the harmony relationship in society. Education level should be more increased. It becomes the most factor needy in this process.

Hoping that through this research may help scientific insights about Christian studies dealing the disruptive area.

\section{References}

[1] Putra, Eka Dharma, (2001), PergulatanKehadiran Kristen di Indonesia, Jakarta, BPK GunungMulia.

[2] Siswanto, Krido (2017), $\quad$ PerjumpaanInjil Dan TradisiJawaTimuranDalamPelayananMisiKontekstual, Diterbitkan pada JurnalEvangelikal: JurnalTeologiInjili dan PembinaanWargaJemaat, STT Simpson Semarang,Volume 1 Edisi 1 tahun 2017, ISSN 2548-7558https://doi.org/10.46445/ejti.v1i1.57

[3] Tampubolon, Yokhebet P (2019), KehidupanDalam Masyarakat MajemukMelalui Pendidikan Kristen Di Jemaat HKBP Manado, diterbitkan pada JurnalMusterion: JurnalTeologiInjili dan Dispensasional, STT Anderson Manado, Volume 1 Edisi 1 tahun 2019, ISSN 2686-3189.

[4] Lumintang, Stevri Indra \&DanikAstuti (2016), TheologiaPenelitian dan PenelitianTheologis Science-A science sertaMetodologinya, Jakarta: GanevaInsani Indonesia

[5] Stott, John (1990), Satu Umat - MenuntunGerejaMenjadiKomunitas Yang Melayani, Malang: Literatur SAAT

[6] Antone, Hope S (2010), Pendidikan KristianiKontesktual, Jakarta: BPK GunungMulia

[7] Packer, J. I \& Thomas C. Oden (2011), Satu Iman - KonsesusInjili, Jakarta: BPK GunungMulia

[8] Guthrie, Donald, TeologiPerjanjianBaru 3 (1996)., pen. LisdaTirtaPrajadkk (Jakarta: BPK GunungMulia

[9] Marantika, Chris (2002), Principles \& Practice of The World Mission, Yogyakarta: Iman Press

[10] Marpaung, Agus M (2017),Gereja Yang Belajar: KajianTentangPendidikanKristendalamGereja, Yogyakarta : Andi Offset

[11] Sinaga, Marthin, (2007) PengantarTeologi Agama-Agama, Meretas Jalan Teologi Agama-Agama di Indonesia, Jakarta: BPK GunungMulia. 
[12] Merino,Stephen (2010), Religious Diversity in a "Christian Nation": The Effects of Theological Exclusivity and Interreligious Contact on the Acceptance of Religious Diversity, Journal For The Scientific Study of Religion, https://doi.org/10.1111/j.1468-5906.2010.01506.x

[13] Adams, Daniel J (2006), Teologi Lintas Budaya (Jakarta: BPK GunungMulia)

[14] Niebuhr, Richard (1995), Kristus dan Kebudayaan, Petra Jaya: Jakarta

[15] Tago, MahliZainudin\&Shonhaji (2013), Agama Dan Integrasi SosialDalamPemikiran Clifford Geertz, JurnalKalam : Studi Agama Dan Pemikiaran Islam,UIN Raden Inten, https://doi.org/10.24042/klm.v7i1.377

[16] Salim, Agus (2013), Javanese religion, Islam or syncretism: comparing Woodward's Islam in Java and Beatty's Varieties ofJavanese Religion, Indonesia Journal of Islam and Muslim Society,IAINSalatiga.https://doi.org/10.18326/ijims.v3i2.223-266 